\title{
INDUKSI MUTASI PADA PISANG (Musa sp. - ABB) cv. KEPOK DENGAN IRADIASI GAMMA SECARA IN VITRO
}

\author{
Luthfia Masykuroh*, Adisyahputra, Reni Indrayanti \\ Prodi Biologi FMIPA Universitas Negeri Jakarta, Indonesia \\ *Email:luthfiamasykuroh@yahoo.com
}

\begin{abstract}
Banana (Musa sp. - ABB) cv. Kepok is one of type banana processed that have a very potential commodities fruit developed to support food survival. The purpose of this study was to knowing the effect of gamma irradiation on the growth of banana plants cv. Kepok in vitro. This study was conducted in October 2014 - October 2015 in Plant Tissue Culture Laboratory, Biological - Science UNJ. The methods used was experiment with fully randomized design. Factors that tested was 6 gamma irradiation doses (0, 20, 30, 40, 50, 60 Gy) with 10 repetition. Observation of phenotypic generate diverse characters on the growth of the number of shoots and leaves. Gamma irradiation dose of $50 \mathrm{~Gy}$ is doses most inhibits the growth of character. Mutations that occur in banana plantlets $\mathrm{cv}$. Kepok generated by the treatment doses gamma irradiation induced mutation is random.
\end{abstract}

Keywords: gamma irradiation, in vitro tissue culture, banana (Musa sp.- ABB) cv. Kepok

\section{PENDAHULUAN}

Pisang merupakan komoditas buah-buahan yang sangat potensial dikembangkan untuk menunjang ketahanan pangan. Pisang memiliki keunggulan yang dibutuhkan seperti kandungn nutrisi, produktivitas yang cukup tinggi dan kemampuan untuk mengatasi tekanan lingkungan sekitarnya untuk dapat bertahan hidup (Deptan, 2006). Pisang merupakan hasil pangan pertanian terpenting keempat di dunia setelah beras, gandum, dan jagung (INIBAP, 2000). Produksi pisang di Indonesia menduduki tempat kelima dunia dengan besaran 3,6 juta ton atau 5 persen dari produksi dunia (Deptan, 2006). Produktivitas pisang di Indonesia pada tahun 2014 mencapai 70.46 ton per hektar dan konsumsi buah pisang penduduk Indonesia mencapai 5,902 kg per kapita setahun (BPS, 2014).

Tanaman pisang merupakan tanaman yang diperbanyak secara vegetatif sehingga memiliki keterbatasan dalam perolehan variasi genetik, serta membutuhkan waktu generasi yang panjang dalam siklus vegetatifnya. Peningkatan keragaman genetik pada tanaman pisang dapat dilakukan melalui induksi mutasi, dan pada saat ini metode pemuliaan dengan mutasi dan bioteknologi untuk peningkatan keragaman genetik dapat menjadi suatu alternatif metode yang bermanfaat bagi pemuliaan tanaman pisang (IAEA, 2009).

Mutasi adalah suatu proses perubahan yang mendadak pada materi genetik dari suatu sel, yang mencakup perubahan pada tingkat molekuler, gen dan kromosom (Poehlman and Sleper, 1995). Proses mutasi dapat menimbulkan perubahan pada sifat-sifat genetis tanaman baik ke arah positif maupun negatif, dan normal. Mutasi yang terjadi ke arah sifat positif dan terwariskan ke generasi berikutnya merupakan mutasi yang dikehendaki oleh pemulia tanaman (Sisworo et al., 2010). 
Percepatan, frekuensi dan spektrum mutasi tanaman dapat diinduksi dengan perlakuan bahan mutagen tertentu. Agen mutagenik seperti pemberian mutagen fisik dan beberapa mutagen kimia dapat digunakan untuk mutasi induksi dan menghasilkan variasi genetik dimana mutan-mutan yang diinginkan kemungkinan dapat diseleksi (Novak dan Brunner 1992; IAEA, 2009). Penggunaan mutagen fisik pada tanaman sangat dianjurkan dibandingkan dengan mutagen kimia, karena frekuensi mutasi yang tinggi (Medina et al., 2004). Salah satu mutagen fisik yang dapat digunakan adalah sinar gamma. Penggunaan energi seperti sinar gamma pada tanaman akan memberikan pengaruh yang baik di bidang pertanian (Suryowinoto, 1987). Oleh karena itu tujuan dari penelitian ini adalah untuk mengetahui pengaruh iradiasi gamma terhadap pertumbuhan tanaman pisang (Musa sp. - ABB) cv. Kepok secara in vitro.

\section{METODE PENELITIAN}

Penelitian ini dilaksanakan di Laboratorium Kultur Jaringan Tanaman, Jurusan Biologi FMIPA Universitas Negeri Jakarta pada bulan Oktober 2014 sampai Oktober 2015. Alat yang digunakan pada penelitian ini adalah kotak transfer (laminar airflow cabinet), tabung reaksi, botol steril, cawan petri, pinset, gunting, bionet, scalpel, lampu spiritus, erlenmeyer, gelas ukur, gelas beaker, autoclave, oven, spatula, timbangan digital dengan ketelitian 0,01 gr, timbangan elektrik dengan ketelitian 0,0001 gr, magnetic stirrer, hot plate, lemari pendingin, pipet hisap, bulb, batang pengaduk, indicator $\mathrm{pH}$ universal, baki, mistar, lampu 18 watt, spidol marker, kamera. Bahan yang digunakan yaitu plantlet tunas aseptis pisang (Musa sp. - ABB) cv. Kepok yang diperoleh dari Laboratorium Kultur Jaringan Pusat Perkembangan Benih dan Proteksi Tanaman Dinas Kelautan dan Pertanian, DKI Jakarta, media Murashige dan Skoog (MS), aquades steril, alkohol 70\%, alkohol 96\%, teepol, klorox ( $\mathrm{NaOCl}$ ), sabun pencuci, sukrosa, antibiotik, $\mathrm{NaOH} 1 \mathrm{M}$ dan HCL 0,1M, spiritus, agar - agar, betadine, plastik penutup, karet gelang, kertas pembungkus, kertas label, kertas saring.

Metode yang digunakan dalam penelitian ini adalah metode eksperimen. Prosedur sampling yang digunakan adalah Rancangan Acak Lengkap (RAL). Faktor yang diuji adalah 6 dosis iradiasi gamma (0, 20, 30, 40, 50, 60 Gy) dengan 10 kali pengulangan, sehingga dibutuhkan 60 unit percobaan. Eksplan tunas pisang kepok aseptis diproliferasi selama 2 bulan dalam media Murashige dan Skoog (MS) dengan penambahan 4.50 mgL-1 6-benzyl amino purine (BAP), $0.22 \mathrm{mgL}-1$ thidiazuron (TDZ) dan $0.175 \mathrm{mgL}-1$ indole-acetic acid (IAA). Induksi mutasi dilakukan di Pusat Aplikasi Teknologi Isotop dan Radiasi - BATAN, Jakarta. Proliferasi tunas dilakukan pada setiap perlakuan dosis iradiasi gamma. Tunas pisang (Musa sp. - ABB) cv. Kepok in vitro yang sebelumnya telah di iradiasi, disubkultur kembali pada media proliferasi sampai 4 kali subkultur selama 20 minggu. Karakter yang diukur pada tahap proliferasi dilakukan setiap 4 - 6 minggu sekali (4 kali subkultur) terhadap jumlah tunas dan jumlah daun

Teknik analisis data, jumlah tunas dan jumlah daun dianalisis dengan melihat rata - rata setiap parameter, standar eror $( \pm$ SE $)$ dan uji F - anava satu arah dilanjutkan dengan uji BNT untuk mengetahui perbedaan perlakuannya. Pengolahan data dilakukan dengan menggunakan program software SPSS v.17.

\section{HASIL DAN PEMBAHASAN}

Tunas hasil induksi mutasi diproliferasi selama 20 minggu dengan 4 kali subkultur. Berdasarkan hasil pengamatan, didapatkan gambaran umum adanya variasi jumlah tunas dan daun setelah perlakuan iradiasi gamma dengan dosis berbeda. Pengamatan rerata jumlah tunas dan daun dilakukan pada planlet pisang cv. Kepok hasil 
iradiasi gamma usia 6 minggu (M1V1), 10 minggu (M1V2), 15 minggu (M1V3) dan 20 minggu (M1V4). Hasil pengamatan rerata jumlah tunas dan daun hasil iradiasi gamma tersebut dibandingkan dengan kontrol untuk melihat perbedaannya.

Tabel 1. Rerata jumlah tunas dan daun planlet pisang cv. Kepok hasil perlakuan iradiasi gamma secara in vitro usia 6 minggu setelah diradiasi dengan 1 kali subkultur (M1V1)

\begin{tabular}{|c|c|c|c|c|c|c|}
\hline \multirow{2}{*}{$\begin{array}{l}\text { Dosis iradiasi } \\
(\mathrm{Gy})\end{array}$} & \multicolumn{3}{|c|}{ Jumlah tunas } & \multicolumn{3}{|c|}{ Jumlah daun } \\
\hline & Rerata & $\begin{array}{l}\text { Perbedaan dengan } \\
\text { kontrol }\end{array}$ & $\pm \mathrm{SE}$ & Rerata & $\begin{array}{l}\text { Perbedaan dengan } \\
\text { kontrol }\end{array}$ & \pm SE \\
\hline 0 & 9.53 & - & 1.35 & 11.71 & - & 1.45 \\
\hline 20 & 14.33 & $4.80^{*}$ & 1.71 & 18.22 & $6.51^{*}$ & 2.95 \\
\hline 30 & 8.09 & -1.44 tn & 1.22 & 12.10 & $0.38 \mathrm{tn}$ & 2.28 \\
\hline 40 & 7.57 & $-1.96 \mathrm{tn}$ & 2.23 & 14.57 & $2.86 \mathrm{tn}$ & 1.02 \\
\hline 50 & 9.75 & $0.22 \mathrm{tn}$ & 2.13 & 9.75 & $-1.95 \mathrm{tn}$ & 2.14 \\
\hline 60 & 7.44 & $-2.09 \mathrm{tn}$ & 1.59 & 7.44 & $-4.26 \mathrm{tn}$ & 1.60 \\
\hline
\end{tabular}

Hasil analisis dengan uji BNT pada planlet pisang cv. Kepok usia 6 minggu dan 10 minggu (M1V1) (M1V2) (Tabel 1 dan 2) menunjukkan bahwa rerata jumlah tunas hasil iradiasi tidak berbeda nyata dengan kontrol (0 Gy) dan jumlah tunas tertinggi terdapat pada dosis iradiasi 20 Gy (14.33) dan (15.56), sedangkan pada pada planlet pisang cv. Kepok usia 15 minggu (M1V3) (Tabel 3) rerata jumlah tunas hasil iradiasi berbeda nyata dengan kontrol (0 Gy) dan jumlah tunas tertinggi terdapat pada kontrol (20.10) (0 Gy).

\begin{tabular}{|c|c|c|c|c|c|c|}
\hline \multirow{2}{*}{$\begin{array}{l}\text { Dosis iradiasi } \\
\text { (Gy) }\end{array}$} & \multicolumn{3}{|c|}{ Jumlah tunas } & \multicolumn{3}{|c|}{ Jumlah daun } \\
\hline & Rerata & $\begin{array}{l}\text { Perbedaan } \\
\text { dengan kontrol }\end{array}$ & $\pm \mathrm{SE}$ & Rerata & $\begin{array}{l}\text { Perbedaan dengan } \\
\text { kontrol }\end{array}$ & $\pm S E$ \\
\hline 0 & 11.88 & - & 2.00 & 11.77 & - & 1.98 \\
\hline 20 & 15.56 & $3.67 \mathrm{tn}$ & 2.94 & 14.22 & $2.46 \mathrm{tn}$ & 3.34 \\
\hline 30 & 9.30 & $-2.58 \mathrm{tn}$ & 1.73 & 11.40 & $-0.37 \mathrm{tn}$ & 2.37 \\
\hline 40 & 5.57 & $-6.31^{*}$ & 1.17 & 8.43 & $-3.34 \mathrm{tn}$ & 2.49 \\
\hline 50 & 8.38 & $-3.51 \mathrm{tn}$ & 2.18 & 7.88 & $-3.89 \operatorname{tn}$ & 1.39 \\
\hline 60 & 7.11 & $-4.77 \mathrm{tn}$ & 1.34 & 14.44 & $2.68 \mathrm{tn}$ & 2.37 \\
\hline
\end{tabular}

Keterangan : ${ }^{*}=$ berbeda nyata dibandingkan kontrol pada taraf $5 \%$ berdasarkan uji BNT; $\mathrm{tn}=$ tidak berbeda nyata dibandingkan kontrol berdasarkan uji BNT . M1V2 : Tanaman hasil mutasi pada siklus vegetatif kedua

Hasil pengamatan pada rerata jumlah daun pada planlet pisang cv. Kepok usia 6, 10 dan 15 minggu (Tabel 1, 2 dan 3) menunjukkan bahwa rerata jumlah daun hasil iradiasi tidak berbeda nyata dengan kontrol (0 Gy). Rerata jumlah daun daun tertinggi pada planlet pisang cv. Kepok usia 6 minggu terdapat pada dosis 20 Gy (18.22), usia 10 
minggu terdapat pada dosis iradiasi $60 \mathrm{~Gy}$ (14.44) dan usia 15 minggu rerata jumlah daun tertinggi terdapat pada dosis iradiasi 60 Gy (14.89).

Tabel 3. Rerata jumlah tunas dan daun planlet pisang cv. Kepok hasil perlakuan iradiasi gamma secara in vitro usia 15 minggu setelah diradiasi dengan 3 kali subkultur (M1V3)

\begin{tabular}{lllllll}
\hline \multirow{2}{*}{ Dosis iradiasi (Gy) } & \multicolumn{5}{l}{ Jumlah tunas } & \multicolumn{3}{l}{ Jumlah daun } \\
\cline { 2 - 6 } & Rerata & $\begin{array}{l}\text { Perbedaan den- } \\
\text { gan kontrol }\end{array}$ & \pm SE & Rerata & $\begin{array}{l}\text { Perbedaan den- } \\
\text { gan kontrol }\end{array}$ & \pm SE \\
\hline 0 & 20.10 & - & 1.92 & 9.43 & - & 1.85 \\
20 & 7.30 & $-12.80^{*}$ & 1.40 & 8.80 & $-0.63 \mathrm{tn}$ & 3.10 \\
30 & 5.89 & $-14.21^{*}$ & 1.31 & 9.11 & $-0.32 \mathrm{tn}$ & 2.78 \\
40 & 3.13 & $-16.97^{*}$ & 0.81 & 7.13 & $-2.30 \mathrm{tn}$ & 1.96 \\
50 & 6.00 & $-14.10^{*}$ & 2.78 & 3.80 & $-5.63 \mathrm{tn}$ & 1.56 \\
60 & 7.78 & $-12.32^{*}$ & 1.60 & 14.89 & $5.46 \mathrm{tn}$ & 3.59 \\
\hline
\end{tabular}

Keterangan : ${ }^{*}$ = berbeda nyata dibandingkan kontrol pada taraf $5 \%$ berdasarkan uji BNT; $\mathrm{tn}=$ tidak berbeda nyata dibandingkan kontrol berdasarkan uji BNT . M1V3 : Tanaman hasil mutasi pada siklus vegetatif ketiga

Hasil analisis dengan uji BNT pada planlet pisang cv. Kepok usia 20 minggu dengan 4 kali subkultur (M1V4) (Tabel 4) menunjukkan bahwa rerata jumlah tunas akibat perlakuan iradiasi memberikan perbedaan yang nyata jika dibandingkan dengan planlet kontrol (0 Gy). Rerata jumlah tunas pisang cv. Kepok hasil iradiasi gamma (20 - 60 Gy) lebih rendah dibandingkan dengan rerata jumlah tunas kontrol (0 Gy). Sedangkan terhadap rerata jumlah daun, pemberian perlakuan iradiasi gamma tidak memberikan perbedaan yang nyata jika dibandingkan dengan kontrol ( 0 Gy), kecuali pada perlakuan hasil iradiasi $50 \mathrm{~Gy}$. Hasil pengamatan tersebut menunjukkan bahwa rerata jumlah tunas tertinggi terdapat pada kontrol ( $0 \mathrm{~Gy}$ ) (33.95) dan terendah pada dosis $50 \mathrm{~Gy}(2.00)$. Rerata jumlah daun tertinggi terdapat pada dosis iradiasi $60 \mathrm{~Gy}$ (11.00) dan terendah pada dosis $50 \mathrm{~Gy}$ (1.33) (Tabel 4).

Tabel 4. Rerata jumlah tunas dan daun planlet pisang cv. Kepok hasil perlakuan iradiasi gamma secara in vitro usia 20 minggu setelah diradiasi dengan 4 kali subkultur (M1V4)

\begin{tabular}{lllllll}
\hline & \multicolumn{3}{c}{ Jumlah tunas } & \multicolumn{3}{c}{ Jumlah daun } \\
\cline { 2 - 7 } Dosis iradiasi (Gy) & Rerata & $\begin{array}{l}\text { Perbedaan den- } \\
\text { gan kontrol }\end{array}$ & \pm SE & Rerata & $\begin{array}{l}\text { Perbedaan den- } \\
\text { gan kontrol }\end{array}$ & \pm SE \\
\hline 0 & 33.95 & - & 3.31 & 8.63 & - & 0.98 \\
20 & 22.65 & $-11.30^{*}$ & 4.85 & 7.29 & -1.34 tn & 1.33 \\
30 & 13.27 & $-20.68^{*}$ & 3.07 & 10.00 & 1.37 tn & 1.54 \\
40 & 19.50 & $-14.45^{*}$ & 12.35 & 6.50 & -2.13 tn & 2.06 \\
50 & 2.00 & $-31.95^{*}$ & 0.58 & 1.33 & $-7.30^{*}$ & 0.33 \\
60 & 9.50 & $-24.45^{*}$ & 1.91 & 11.00 & $2.37 \mathrm{tn}$ & 1.73 \\
\hline
\end{tabular}

Keterangan : ${ }^{*}=$ berbeda nyata dibandingkan kontrol pada taraf $5 \%$ berdasarkan uji BNT; $\mathrm{tn}=$ tidak berbeda nyata dibandingkan kontrol berdasarkan uji BNT M1V4 : Tanaman hasil mutasi pada siklus vegetatif keempat

Hasil pengamatan terhadap jumlah tunas pisang cv. Kepok menunjukkan bahwa peningkatan dosis iradiasi gamma berpengaruh terhadap penurunan jumlah tunas (Tabel 4.). Hasil penelitian ini menunjukkan bahwa 
jumlah tunas tertinggi dijumpai pada kontrol (0 Gy) (33.95). Hal tersebut sesuai dengan hasil penelitian Suhartini (1992) yang menyatakan bahwa dengan meningkatnya dosis radiasi sinar gamma akan menurunkan jumlah tunas, dan persentase tanaman hidup. Hal ini karena iradiasi yang tinggi dapat menyebabkan enzim yang merangsang pertunasan menjadi tidak aktif, sehingga pertumbuhan tanaman terhambat (Prayitno dan Nastiti, 1979; Oktavina, 2011). Jumlah tunas yang terbentuk pada dosis iradiasi $30 \mathrm{~Gy}$ (13.27) lebih rendah dibandingkan dengan dosis 40 Gy (19.50), begitu juga jumlah tunas pada dosis iradiasi $50 \mathrm{~Gy}$ (2.00) lebih rendah dibandingkan dengan dosis iradiasi 60 Gy (9.50) (Tabel 4), hal ini dapat disebabkan oleh perbedaan tipe jaringan tanaman dan letak posisi tanaman pada saat diradiasi. Jaringan yang masih muda akan lebih sensitif terhadap iradiasi gamma.

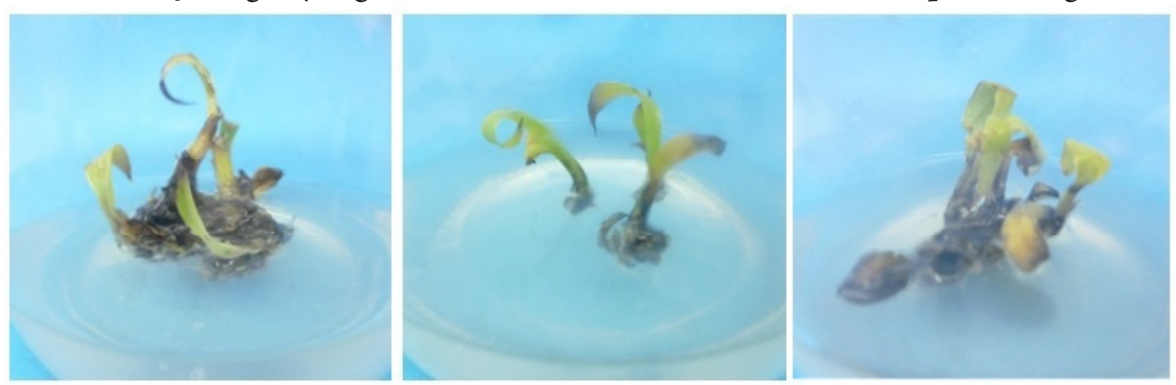

Gambar 1. Daun planlet pisang cv. Kepok hasil iradiasi gamma dosis 50 Gy yang layu dan mati akibat iradiasi

Kerusakan fisiologis yang diakibatkan oleh iradiasi gamma dapat berupa kematiaan sel, terhambatnya pembelahan sel, peningkatan frekuensi pembentukan jaringan dan perubahan pada kapasitas bereproduksi. Selain itu juga dapat menyebabkan mutasi, sehingga daun berukuran lebih kecil dari yang tidak diberi perlakuan (Bakri, 2002; Suwarno, 2013).

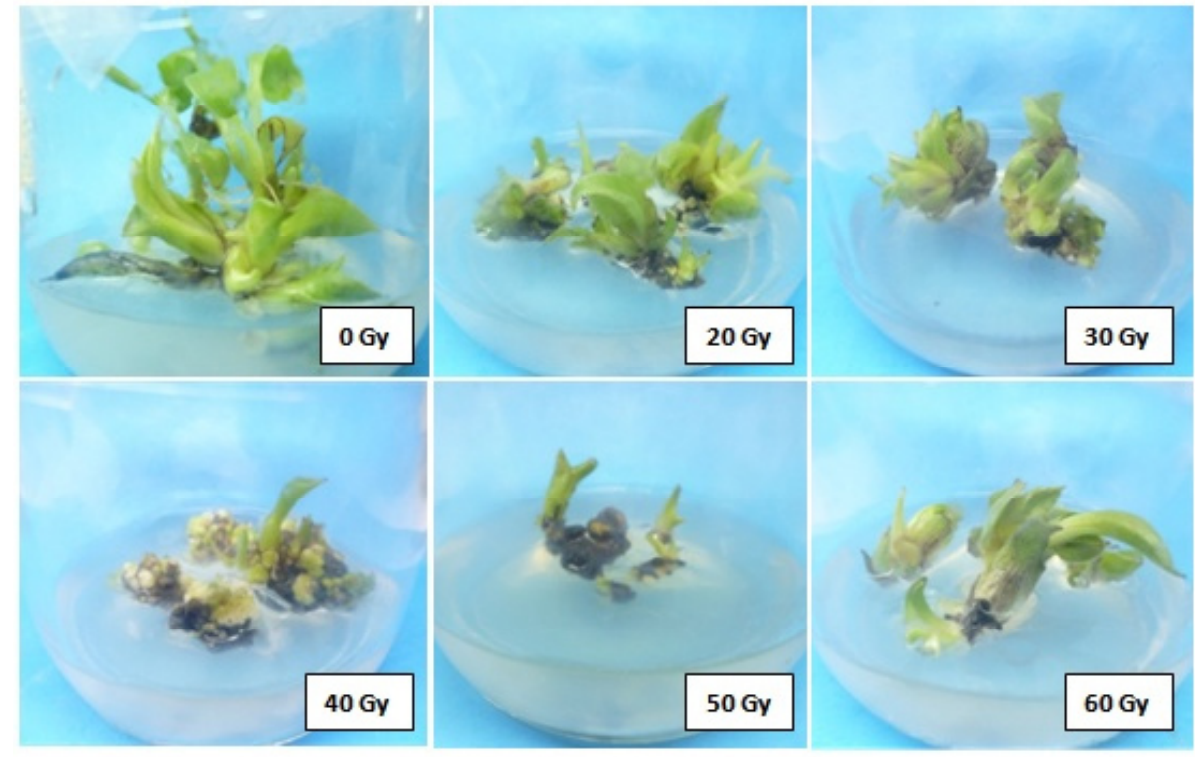

\section{Gambar 2. Planlet pisang cv. Kepok hasil perlakuan iradiasi gamma secara in vitro usia 20 minggu setelah diradiasi dengan 4 kali subkultur (M1V4)}

Pengamatan daun sangat penting sebagai acuan pertumbuhan dan perkembangan tanaman, karena daun merupakan salah satu organ penting tanaman sebagai tempat fotosintesis dan juga sebagai perkembangan lebih lanjut 
dari tunas yang telah tumbuh pada eksplan. Tanda paling awal akan adanya perkembangan daun adalah pembelahan sel terluar yang diikuti dengan pertumbuhan sel anak yang menyebabkan timbulnya tonjolan yaitu primordial daun. Pertumbuhan daun merupakan proses diferensiasi tunas (Salibury dan Ross, 1992 ; Oktavina, 2011).

Hasil penelitian Indrayanti et al (2011) pada cv. Ampyang menunjukkan bahwa jumlah daun tertinggi dijumpai pada dosis 40 Gy, sedangkan pada penelitian Kusumastuty (2012) menunjukkan bahwa jumlah daun tertinggi dijumpai pada tanaman kontrol (0 Gy). Pada penelitian ini jumlah daun tertinggi dijumpai pada dosis 60 Gy (11.00) dan terendah pada dosis 50 Gy (1.33) (Tabel 4.). Hal ini berbeda dengan pernyataan Gaul (1997) yang menyebutkan bahwa jumlah daun hasil iradiasi lebih rendah dibandingkan dengan kontrol. Data tersebut menunjukkan bahwa mutasi yang terjadi pada jumlah daun bersifat acak.

Iradiasi Gamma pada dosis tinggi dapat mengganggu sintesa protein, keseimbangan hormon, pertukaran gas pada daun, pertukaran air dan aktifitas enzim (Hammed et al., 2008; Borzouei et al., 2010; Suwarno, 2013). Natawijaya et al., (2009), menyatakan bahwa daun yang mati karena efek iradiasi dicirikan dengan daun yang berwarna cokelat dan kering. Pada penelitian ini hal tersebut terjadi pada planlet pisang cv. Kepok hasil iradiasi gamma dosis 50 Gy (Gambar 1.) iradiasi dapat mendegradasi klorofil pada daun, sehingga dapat mengganggu proses fotosintesis dan pada akhirnya akan mengalami kematian.

Pengaruh iradiasi sinar gamma bersifat acak, yakni dapat bersifat positif dengan sifat karakter yang baik sesuai karakter yang diinginkan, maupun bersifat negatif dengan muculnya karakter yang tidak dikehendaki. Hasil penelitian ini menunjukkan bahwa mutasi yang terjadi pada jumlah tunas dan daun bersifat acak. Hal tersebut sesuai dengan Medina et al., (2004) yang menyatakan bahwa teknik induksi mutasi dengan iradiasi gamma menyebabkan terjadinya mutasi secara acak, sehingga fenotipe mutan yang didapatkan juga bersifat acak. Meskipun masih pada tahapan planlet, adanya keragaman fenotipik untuk berbagai karakter yang diamati dapat menjadi indikasi terjadinya mutasi pada planlet yang didapat. Namun demikian, evaluasi lebih lanjut memang masih perlu dilakukan pada tingkat bibit dan tanaman di lapangan. Jika terbukti bahwa keragaman fenotipik pada tingkat in vitro yang diamati untuk plantlet pisang cv. Kepok hasil perlakuan iradiasi gamma ternyata benar disebabkan oleh mutasi, maka populasi bibit yang dihasilkan dalam penelitian ini dapat diseleksi untuk mengidentifikasi varian atau mutan yang mempunyai sifat unggul tertentu seperti kualitas dan kuantitas buah yang lebih baik atau memiliki ketahanan terhadap penyakit.

Identifikasi tanaman varian hasil iradiasi secara in vitro dilaporkan lebih efektif (Predieri, 2001), karena induksi mutasi dilakukan pada sekelompok sel atau jaringan, sehingga probabilitas untuk terjadinya mutasi genetik atau epigenetik yang dapat diekspresikan sebagai perubahan fenotipik menjadi lebih besar (Harrison dan Schwarzacher, 2007).

\section{KESIMPULAN}

Planlet pisang cv. Kepok hasil iradiasi gamma menghasilkan variasi fenotipik pada karakter pertumbuhan jumlah tunas dan daun. Iradiasi gamma dosis 50 Gy paling menghambat karakter pertumbuhan tersebut. Mutasi yang terjadi pada planlet pisang cv. Kepok yang dihasilkan oleh perlakuan dosis induksi mutasi iradiasi gamma bersifat acak sehingga menghasilkan variasi fenotipik yang beragam.

\section{DAFTAR PUSTAKA}

[BPS] Badan Pusat Statistik. 2014. Produksi buah-buahan di Indonesia. http://www.bps.go.id. 22 Desember 2014 
pkl. 15.30 WIB.

[Deptan] Departemen Pertanian. 2006. Pusat Data dan Informasi Pertanian. http//www.deptan.go.id. 7 November 2014 pkl. 13.27 WIB.

Gaul. 1977. Mutagen effect in the first generation after seed treatment : plant injury and lethality. p. 29-36. In IAEA: Manual on Mutation Breeding. 2nd ed. Joint FAO/IAEA Division of Atomic Energy in Food and Agriculture.

Harrison, H.J.S., T. Schwarzacher. 2007. Domestication, genomics and the future for banana. J. Ann. Bot. Rev Vol : 100:1073-1084.

[IAEA] International atomic energy agency. 2009. Induced mutation in tropical fruits trees. Plant breeding and genetic section. Vienna. IAEA - TECDOC - 1615.

Indrayanti, R., Nurhajati Ansori Mattjik., Asep Setiawan., Sudarsono. 2011. Radiosensitivitas Pisang cv. Ampyang dan Potensi Penggunaan Iradiasi Gamma untuk Induksi Varian. J.Agron. Indonesia. Vol. 39 (2) : 112 118.

[INIBAP] International Network for the Improvement of Banana and Plantain. 2000. Bananas., International Plant Genetic Resources Institute. http://bananas.bioversityinternational.org/files/files/pdf/publications/ brochure_banana s.pdf

Kusumastuty, E. 2012. Aklimatisasi dan Evaluasi Keragaman Fenotipik Tanaman Pisang (Musa spp.) cv. Barangan Merah Hasil Iradiasi dengan Sinar Gamma. Skripsi. Universitas Negeri Jakarta : Jakarta.

Medina F-IS, Amano E, Tano S. 2004. Mutation Breeding Manual, Japan. Forum For Nuclear Coorporation in Asia (FNCA)

Natawijaya, A., Afiyata, A., Ritonga, A.W. 2009. Pengaruh Iradiasi Sinar Gamma Terhadap Keragaman Planlet Tanaman Gloxinia. Skripsi. Jurusan Pemuliaan dan bioteknologi Tanaman. Agronomi dan Holtikultura. IPB. Bogor

Oktavina, Z. 2011. Pengaruh Iradiasi Sinar Gamma Terhadap Pertumbuhan Anggrek Hibrid Dendrobium Schulerii X May Neal Wrap secara In Vitro. Skripsi. UIN. Jakarta.

Poehlman, J. M., and D. A. Sleper. 1995. Breeding Field Crops. Iowa State University Press. J. Ames. 432 p.

Predieri, S. 2001. Mutation induction and tissue culture in improving fruits. J.Plant Cell Tiss. Org. Cult. Vol. 64:185210.

Sisworo, W.H., Wandowo, Ismachin, dan Elsje, L.S. 2010. Isotop dan Radiasi untuk kemajuan usaha anda. Pusat Aplikasi Teknologi Isotop dan Radiasi (PATIR-BATAN). Jakarta.

Suhartini, T. 1992. Pengaruh Radiasi Corm dengan Sinar Gamma Terhadap Keragaman Pertumbuhan dari Bunga Gladiol (Gladiolus hybridus), Thesis Jurusan Budidaya Pertanian, IPB, Bogor

Suryowinoto, M. 1987. Tenaga Atom dan Pemanfaatannya dalam Biologi Pertanian. Kanisius. Yogyakarta.

Suwarno A, Noor A H, Lina H. 2013. Respon Pertumbuhan Planlet Anggrek Phalaeonopsis amabilis L. Var. Jawa Candiochid Akibat Radiasi Sinar Gamma. Unnes J Life Sci. Indonesia 2 (2) : 78 - 84. 